\title{
Medicina do Esporte: passado, presente e futuro, buscando melhorar a qualidade de vida através da atividade física
}

\author{
Eduardo Henrique De Rose
}

Certamente, o início da Medicina do Esporte se encontra em algum lugar do passado, bem próximo ao começo da existência da humanidade. Entretanto, formalmente, o primeiro documento que mostra claramente a influência do exercício no tratamento de doenças é o Papirus Ebers, escrito pelo médico hindu Susrota no ano 1550 a.C. Este famoso médico do Império Mughal, uma das civilizações indianas mais importantes, sabia não apenas diagnosticar essa enfermidade através da glicosúria, como também tratar seus pacientes com dieta e atividades físicas, tais como a luta e longos percursos montando elefantes.

Os filósofos gregos, em especial Platão, valorizavam extremamente as atividades físicas regulares como forma de buscar harmonia, que era um dos sinônimos mais utilizados na época para definir saúde. Desse conceito surgem os Jogos Olímpicos, como forma de festival religioso que visava promover um corpo saudável, harmônico e bonito como o templo ideal para os deuses da época. A primeira manifestação desses jogos foi uma corrida no Vale de Olímpia, que dava ao vencedor o honroso direito de acender o fogo sagrado a Zeus.

Um dos maiores médicos do período grego, Esculápio, criou perto de Atenas um hospital com características únicas. Além do bloco cirúrgico e das enfermarias clínicas, tinha ainda um anfiteatro e um ginásio de esportes, expressando pela primeira vez o conceito do tratamento biopsíquico das enfermidades, usando como co-fatores o drama e a atividade física regular.

Os médicos romanos, que completam o ciclo dos precursores de nossa especialidade, nos ensinaram a prescrever exercício, definindo a importância da intensidade como uma variável fundamental na atividade física regular. Sem possuir medidores acurados do tempo, da freqüência cardíaca ou do lactato, usaram a única variável que conheciam ser eficiente: a sudorese. Através dela, definiam intensidades ideais de exercício, que hoje seriam ditas aeróbias, e que são indicadas para tratamento de patologias degenerativas através da atividade física.

As peças de teatro da Idade Média, época crepuscular de todas as ciências, mostram que continuava clara e forte a idéia de que, para obter qualidade de vida, o exercício era importante, como era também saber beber e comer adequadamente, saber conviver adequadamente com a alegria e a preocupação, e saber alternar corretamente a atividade física e o repouso.

A redescoberta do valor da atividade física como co-fator do tratamento de patologias endócrinas surgiu no século XIX, através de médicos franceses, e na década de 60 o exercício se estabelece como um agente importante na prevenção, tratamento e reabilitação das patologias cardiovasculares.

Do ponto de vista acadêmico, Silvy considera que efetivamente a Medicina do Esporte começa em 1900, com o livro A Higiene do Esporte. O eco dessa publicação na área médica foi muito grande e como conseqüência surge o I Congresso de Medicina do Esporte, realizado em 1915 na França, em Paris.

A I Grande Guerra interrompeu o começo dessa nova especialidade médica e apenas após o fim desse conflito mundial é que a Federação Internacional de Medicina do Esporte foi fundada, nos II Jogos Olímpicos de Inverno, realizados na Suíça, em Saint Moritz. Médicos de 11 países participaram da reunião oficial, realizada no dia 14 de fevereiro de 1928 , tendo a nova entidade como principais objetivos o desenvolvimento de associações nacionais e a troca de informações e experiências no atendimento de atletas.

Hoje é possível dividir o desenvolvimento da moderna Medicina do Esporte em três períodos distintos. De 1928 a 1939 , entre as duas guerras mundiais, essa especialidade era puramente européia. Depois de 1946, quando a FIMS foi reconhecida pelo Comitê Olímpico Internacional e pela Organização Mundial da Saúde, tornou-se entidade verdadeiramente internacional, responsável em especial pelos aspectos médicos e científicos da participação de atletas em competições esportivas. Por último, depois dos Jogos Olímpicos de Munique, a FIMS se desvincula do movimento olímpico, organiza seu próprio congresso mundial e, além de preocuparse com o problema do atleta, começa a investigar também a influência do exercício físico no não atleta, em especial na prevenção, tratamento e reabilitação de patologias de diversos tipos. A influência da atividade física regular na qualidade de vida do homem na sociedade moderna tornou-se um importante aspecto focal que uniu definitivamente a Medicina do Esporte e a Medicina do Exercício, que hoje convivem harmoniosamente em nossa Federação Internacional.

Hollmann considera que o termo Medicina do Esporte, ainda que tradicional, não mais corresponde hoje em dia ao 
corpo de conhecimento desta especialidade. Segundo esse autor, a definição da especialidade, proposta por ele em 1958, engloba os campos teóricos e práticos da Medicina em que se investiga a influência da atividade física, do treinamento e do esporte em pessoas saudáveis e doentes, visando produzir efeitos positivos na prevenção, tratamento e reabilitação de patologias, bem como no desempenho do atleta.

Em 1967, o Comitê Olímpico Internacional cria a sua própria Comissão Médica, presidida pelo príncipe Alexandre de Merode, em função de diversos problemas de doping e de controle de feminidade nos Jogos Olímpicos de Roma e Tóquio. No primeiro grupo de médicos que integra essa comissão encontram-se diversos representantes da FIMS, entre os quais seu presidente Giuseppe La Cava, da Itália, e os vicepresidentes Albert Dirix, da Bélgica, e Ludwig Prokop, da Áustria. O primeiro objetivo da Comissão Médica do COI foi, sem dúvida, assegurar através de controles médicos a ética dos Jogos Olímpicos. Hoje, entretanto, suas atividades incluem também ações nas áreas de Educação e Ciência.

Quando se pensa e fala em qualidade de vida, é importante também observar as modificações que se processaram nos últimos 20 anos nos conceitos de exercício e saúde. Enquanto nos anos 70 e 80 o principal era correr e buscar o condicionamento físico (fitness), nos anos 90 passaram a ser mais valorizadas a caminhada e a qualidade de vida (wellness).
Concluindo, a moderna Medicina do Esporte apresenta três ramificações principais. A primeira, e a mais antiga, é Federação Internacional de Medicina do Esporte e suas associações nacionais afiliadas. A segunda é a Medicina do Esporte Olímpica, coordenada pela Comissão Médica do COI, com suas organizações continentais e nacionais. A terceira é representada pelas Federações Internacionais de Esportes e suas ramificações regionais e nacionais.

No limiar de um novo século, os especialistas desta área e suas entidades de classe, entre elas a Federação Internacional de Medicina do Esporte, estão-se preocupando claramente com a qualidade de vida, recomendando exercícios menos intensos e mais agradáveis, juntamente com uma dieta adequada, realizados em meio ambiente ideal, com baixa poluição e com visual atraente. As atividades esportivas organizadas, por sua vez, como os Jogos Olímpicos e campeonatos internacionais, têm suas sedes escolhidas muitas vezes em função do aspecto meio ambiente, valorizando extremamente a qualidade de vida dos habitantes dessas cidades e dos visitantes que a ela acorrerão durante os Jogos, e pensando também na influência que a poluição ambiental exerce sobre o desempenho atlético.

Dessa forma, não existe a menor dúvida de que o terceiro milênio nos orientará para buscar a qualidade de vida como primeira variável relacionada com a atividade física regular, a saúde e o desporto de alto rendimento. 